\title{
Insurance Distribution Carried Out by Insurers in Spain
}

\author{
Javier Vercher-Moll
}

\section{Introduction}

When legal operators embark on the study of insurance law, they must delineate which part of this regulatory block will be the object of their study. The law of private insurance can be defined as "the set of legal norms that specifically discipline the status of the private insurer, that of its collaborators and that of the insurance contract". 'This is an area in which rules of public and private law converge, and this convergence is most acute in the hierarchy of applicable sources. ${ }^{2}$

The status of the private insurance entrepreneur is currently regulated by Law 20/2015, of July 14, on the organization, supervision and solvency of insurance and reinsurance entities, which transposes Directive 2009/138/EC of the European Parliament and of the Council of 25 November 2009 on the taking-up and pursuit of the business of Insurance and Reinsurance (Solvency II). The collaborators of the insurer, whose activity is focused on the distribution or production of insurance, either directly by the insurer or through a third party, is regulated mainly by Law 26/2006, of July 17, of insurance and private reinsurance mediation, which transposes Directive 2002/92/EC of the European Parliament and of the Council of 9 December 2002 on insurance mediation into the Spanish legislation. Finally, the insurance contract constitutes the third regulatory block of the private insurance system, and it is regulated by Law 50/1980, of October 8, on the Insurance Contract.

This study has been carried out as part of the Research Project I+D "Hacia una protección del cliente más global". AICO2019/075. Generalitat Valenciana.

${ }^{1}$ Sánchez Calero (1961), p. 14.

${ }^{2}$ Del Caño Escudero (1971), p. 11.

J. Vercher-Moll $(\bowtie)$

University of Valencia, Valencia, Spain

e-mail: javier.vercher@uv.es 
The legal regime applicable to the insurer can be divided into four fundamental sections: access to the insurance activity, that is, the insurance company's capacity to insure the assets of the insured party before an accident; the exercise of the activity, that is the guidelines that exist to safeguard the solvency of the insurance company so that it can provide the compensation to which it is contractually obliged; the system of infractions and penalties designed to prevent situations created by the insurance company that could endanger the solvency of the entity, or harm the insurance market in general; and finally, the intervention regime of the insurance entity that can the revoke its administrative authorization, and order its dissolution and liquidation.

A novel feature of this regulatory regime, and one that has not been the subject of attention to date, is the sale of insurance by the insurance company itself, a matter regulated by the new Directive (EU) 2016/97 of the European Parliament and of the Council of 20 January 2016 on insurance distribution. A priori, such regulation could be seen as superfluous because it is obvious that the insurer, as a commercial company, can offer and sell its services just like any other. In this sense, it would seem that nothing new is added by art. 10 of the Directive, given that it simply recognizes the factual circumstance that insurance companies demonstrate their corporate objective by contracting their products with customers.

However, despite this apparent superficiality, the justification for the article is that it imposes the same contractual obligations on all operators that offer insurance, so that differences between them are overcome for the benefit of uniformity. ${ }^{3}$

The preparatory work that led to the Directive ${ }^{4}$ evidences the concern of the European Commission for mediation in private insurance. The objectives of the Directive are : to attempt to resolve the differences in consumer protection that depend on where the product is purchased, to eliminate conflicts of interest between the consumer and the seller of insurance products occasioned by the remuneration of the latter; to overcome deficiencies in the information provided on the insurance product, whether due to bias caused by the insurance seller's system of compensation, or by insufficient technical training of the insurance sales personnel; to regulate the penalties that may be imposed in relation to the sale of insurance; and to promote access to cross-border markets, both through the free provision of services and the right of freedom of establishment.

The Directive attempts to answer the criticisms made by legal scholars ${ }^{5}$ regarding Directive 2002/92/EC of the European Parliament and of the Council of 9 December 2002 on insurance mediation, which excluded the sale of insurance through the insurance company itself from the mediation activity. Thus, insurance companies are now considered to be insurance distributors, which places them on equal terms with respect to other distributors.

\footnotetext{
${ }^{3}$ Hofmann et al. (2018), p. 743.

${ }^{4}$ COM (2012) 360 final, SWD (2012) 191 final.

${ }^{5}$ Bataller Grau (2007), pp. 112-113.
} 
The new Directive establishes the same conditions of competition for all insurance distributors, which benefits insurance consumers, as it makes it easier for them to enjoy the same level of protection despite the obvious differences between the distribution channels. It is an example of the phenomenon known as "Mifidization", after the Mifid regulations for the sale of insurance. ${ }^{6}$

The term "Mifidization" refers to the increase of consumer protection standards in insurance, even though the Mifid regulations do not apply to a specific insurance product. This impact on insurance affects the legal regulatory sources of insurance, the design of insurance products and their distribution, the protection of consumers, and the interpretation of the regulations governing life insurance. ${ }^{7}$

From the 2002 Directive up until the present day the legal panorama of the insurance business has changed radically. The reforms introduced in the areas relating to contractual information and the supervision and solvency of insurance entities, together with the constant evolution of the case-law interprets the insurance contract, obliges us to explain the transcendence of this precept within the existing regulatory framework.

From a contractual point of view, insurance companies that contract directly with their clients must act on equal terms with respect to other insurance distributors, so that there is no distinction with regard to their the duty to provide information on insurance products. ${ }^{8}$

In order to ensure equality among insurance distributors, the Directive also introduces an important novelty, as it requires compliance with certain subjective criterion of the employees of any company that distributes insurance, as well as of their insurance sales directors and managers. It is therefore pertinent to consider whether the regulation represents, not only a reformulation of the system of governance of insurance companies, but also whether, in attention to the principles of corporate governance and supervision it contains, the Directive will require the reformulation of the internal infrastructure of insurance companies, the concepts of the honourability and aptitude that must be shown by their employees, and the powers granted to the supervisory authorities of the Member States.

The problems posed by the Directive are not simple, because they might entail an urgent reform of current regulations.

From the perspective of corporate governance, it is worth asking whether the four fundamental areas that make up the governance system of insurance companies have become obsolete. The direct sale of insurance by insurers requires the creation of a new, autonomous area to complement the companies' systems of governance, and this begs the question of whether the reform of corporate governance is therefore necessary.

\footnotetext{
${ }^{6}$ Marano (2017b), p. 10.

${ }^{7}$ Marano (2017a), p. 416.

${ }^{8}$ Quintans Eiras (2018), pp. 373-420; Miranda Serrano (2017), pp. 287-320; Peñas Moyano (2017), pp. 321-340.
} 
The Directive requires certain subjective requirements of sales staff. They must have sufficient knowledge, skills and honorability to perform such work. These criteria deserve further examination as they contain important details regarding the training that the employees of the insurance company must have, who must possess the quality of honorability and what it means to be honorable in this context.

In any case, the Directive is a minimum standard. It lays down the minimum bases for Member States to transpose the Directive into their national law. This can generate both benefits and drawbacks. As a benefit, States may increase the level of consumer protection but, as a disadvantage, this may result in the level of protection of insurance consumers not being the same in each country.

\section{Governance System of Insurance Companies}

Articles 258 to 272 of the Commission Delegated Regulation (EU) 2015/35 establish the regulation for the system of governance of insurance companies. All insurers and reinsurers are required to have an effective system of governance that guarantees the sound and prudent management of the activity and that is proportionate to its nature, volume and the complexity of its operations.

The company's system of governance must encompass the following functions: risk management, compliance verification, and internal and actuarial audits. In addition, it must contain written corporate governance policies that will include, among others, a transparent and appropriate organizational structure, with a clear distribution and adequate separation of functions, effective mechanisms to guarantee the transmission of information, and remuneration policies and practices adapted to suit the characteristics of the companies. ${ }^{9}$

Remuneration is one of the areas focused upon in the new Directive. Article 17.3 determines that "insurance distributors are not remunerated or do not remunerate or assess the performance of their employees in a way that conflicts with their duty to act in accordance with the best interests of their customers. In particular, an insurance distributor shall not make any arrangement by way of remuneration, sales targets or otherwise that could provide an incentive to itself or its employees to recommend a particular insurance product to a customer when the insurance distributor could offer a different insurance product which would better meet the customer's needs". This provokes a situation which, as legal scholars have pointed out, leads to the coexistence of two types of remuneration: fixed remuneration for salaries or fees and variable remuneration based on the commissions earnt on the volume of insurance policies sold. ${ }^{10}$

The question which needs to be examined here is how article 10 fits into the system of corporate governance outlined in the Directive, as, from a first reading of

\footnotetext{
${ }^{9}$ Tapia Hermida (2016), pp. 331-350.

${ }^{10}$ Hofmann et al. (2018), p. 749.
} 
the text, direct sales do not seem to have a place within the framework of internal functions it creates for insurance companies.

It goes without saying that the Directive imposes a series of minimum requirements for the corporate governance of insurance companies, and that, having delimited these functions as those that are essential for the healthy and prudent management of insurance entities, the law requires that insurance companies incorporate them into their organizational structures. The exact area in which direct sales can best be included needs to be established, and this task entails an analysis of each of the areas covered by the Directive.

Risk management includes all the strategies, procedures and information processing necessary to identify, measure, monitor, manage and continuously report on the risks to which, both individually and in aggregate, the company faces. The risk management system must be effective and fully integrated into the organizational and decision making structures of the company, and has to cover directors or those that exercise managerial authority over the company. Insurance and reinsurance companies have to establish a risk management function to facilitate the application of the system.

The compliance verification function must advise management about compliance with any legal, regulatory and administrative provisions affecting the company, as well as compliance with its internal regulations. This has to include evaluations of the impact of any modifications of the legal environment on the company's operations and the determination and evaluation of compliance risk.

The internal audit includes checking the adequacy and effectiveness of the internal control system and other elements of the company's governance system. The internal audit function should be objective and independent of the operational functions. The conclusions and recommendations derived from the internal audit must be notified to the management body, which will determine what actions should be taken with respect to each of them and ensure that such actions are carried out.

Finally, with respect to the actuarial function, this must be carried out by people who have sufficient knowledge of actuarial and financial mathematics, in accordance with the nature, volume and complexity of the risks inherent to the activity of insurance or reinsurance companies, and who can accredit relevant experience in relation to professional and other applicable standards.

Having briefly examined these four fundamental functions of the entities, it is pertinent to question whether there is a place for direct sales in any of them according to their nature. In the opinion of the author, the direct sales of an insurance company are the maximum expression of the deployment and development of the company's corporate purpose. Direct sales generate risks that must be controlled and monitored by the risk management unit, so a priori, the sale of insurance could be channeled through this area. However, maintaining such a position would result in diminishing the importance of the risk function, which monitors not only those risks derived directly from the corporate purpose, but also those of any another nature that are not related to the sales activity. 
It is therefore worth pondering whether director sales should constitute a specific area that must necessarily be provided, in the image and likeness of other functions, with specific policies and procedures.

\section{A New Area?}

If I analyze the organizational structure of the insurance companies that operate in the Spanish market, I may observe the enormous development enjoyed by the commercial units in recent decades. Not surprisingly, it is a function of great importance because, as previously indicated, it implies the deployment of the company's corporate purpose.

Direct sales by insurance companies will involve the creation of a specific area, equipped with specific policies, with appropriate and updated procedural manuals, as well as, with an orderly and modern infrastructure. All of this is necessary in order to: respect the rights of customers, quickly and efficiently manage the coverage or claims, and minimize the risks and, therefore, the damages that can be generated to the company itself, as well as improving the efficiency of management so as to maximize the company's profit.

This area should be controlled by the other areas that make up the insurance company's governance system. I can consider that the commercial area is the place where the activity of the insurance company is fully developed. It is the area that is in contact with the company's client: the one that contracts, the one that knows the daily needs of the clients, etc. For all these reasons, the rest of the areas of the government system must control this area from different prisms.

The compliance area must review insurance contracts, abusive clauses, customer information, contract updates, etc. The risk area must review the company's risk limit according to the volume of insurance policies, must also review the accident rate, must review if there are claims against the insurance company, must create a contingency plan exclusively for the commercial area, etc.

The actuarial area must review the matching of flows with the accident rates, so that the insurer can pay the indemnities to the insured. The internal audit area must review the policies of the commercial area, the updating of its procedure manuals, the benefits it generates for the insurer, proposals for improvement in the management of the commercial area, etc.

An efficient management of the commercial area will be important for the future development of the insurance company. On the one hand, this area will provide important information to the marketing area in order to know how to design advertising, to emphasize the characteristics of the company's insurance policies, to orient advertising towards certain groups of people. On the other hand, the information from the commercial area will also be important for the development of new businesses, that is, to know the new needs of the insurance company's clients and, therefore, to create insurance policies that adjust to the new needs of the insured. 
Finally, the commercial area will offer information on the reputational value that the insurer has in the insurance market. If the commercial area has direct contact with the client, thanks to the surveys, it will be able to know the clients' opinion about the company. This information is important for the insurance company's management team. Managers will be able to evaluate not only the insurance company's turnover, but also people's opinions about the company.

Thus, according to article 17 of the Directive, advertising communications made by insurance companies to customers or potential customers must be accurate, clear and not misleading, as well as clearly identifiable as such. Consequently, the decisions of the clients will be informed, that is, the client will have full conviction of the insurance product that he/she is going to contract. In this point, the insurance sales area has an important responsibility, given that it knows the type of clients and their needs, to not target consumers with biased advertising communications designed to affect the free decision making capacity of customers or prospective customers. In this sense, it must promptly inform the Marketing Area of the limits of the advertisements it creates.

The fundamental idea contained in article 20 of the Directive is that before the conclusion of an insurance contract, the insurance distributor must specify, based on information obtained from the client, the requirements and needs of said client and provide the client with objective information about the insurance product in a comprehensible manner, so that the client can make an informed decision.

At this point, I should focus on the analysis of the subjective requirements of the employees of the insurance company, because the new Directive emphasizes the technical capacity of the people who distribute insurance through the company, in order to strengthen the company's governance system and guarantee the rights of its customers.

\section{The Requirements of Good Repute}

Article 10 of the Directive is dedicated to regulating the details of the distribution activity by insurance companies. In its first paragraph, it states that insurance companies must ensure that the employees who participate directly in insurance distribution activities, the people responsible for the distribution activity, or, where appropriate, those who are part of the management body responsible for the distribution activity, meet the requirement of commercial and professional honorability.

Without prejudice to the analysis of the requirement of commercial and professional honorability, the article refers directly to a group of people that form the core of the distribution activity within the company. 
The subjective requirements demand that the staff affected by them have sufficient authority to manage the destiny of part of the company. ${ }^{11}$ That is, unlike the regulations applicable to entities operating within the financial markets, the Directive amplifies the reach of certain subjective requirements to the collective, given that the person who has effective contact with the client shall also be subject to assessment.

To assess a person's commercial honor, it is necessary to study the commercial history, the sanctions imposed, the investigations on the person, etc. The problem is that there is no mathematical rule that solves whether a person has a good reputation. The Spanish regulations have made an important effort to detail the Directive, in order to determine whether the persons responsible for the commercial area, and the employees, have a good commercial reputation. In any case, it will be the supervisor of each country who will have the capacity to determine whether a director or an employee of the commercial area of the insurer is honorable.

The aforementioned persons must meet the requirements of commercial and professional honorability provided in art. 2.19 of the Spanish Law 3/2020. ${ }^{12}$ The definition of these concepts offered in this article indicates that they consist of the "quality applicable to those that have observed a personal trajectory of respect for commercial or other laws that regulate economic activity and business life, as well as to good commercial, financial and insurance practices. Said condition shall apply to those persons who do not have a criminal record for having committed criminal offences related to the exercise of financial activities, and who have not been sanctioned in the administrative field in insurance, banking, the securities market, Public Finance, Social Security, Competition Law, the movement of capital, economic transactions abroad, money laundering and the financing of terrorism and the protection of consumers and users, for the commission of offences classified as very serious or serious. The disqualification from the exercise of public or administrative positions and from the management of financial entities, as well as that declared in accordance with Law 22/2003, of July 9, on Insolvency, until the period of fixed disqualification, or the state of bankrupt or not rehabilitated bankrupt in the case of insolvency proceedings prior to the entry into force of the aforementioned law, shall also be considered as circumstances that do not allow for compliance with the honorability requirement".

From a first reading of this paragraph, it would seem that the requirement of honorability is based on a broad concept, whose margin of appreciation by the Dirección General de Seguros y Fondos de Pensiones is extensive. However, it can be reduced to a series of specific and relatively simple questions. In effect, any person who does not have a criminal record, or who has not received sanctions or disqualification from the exercise of public office or from the administration and

\footnotetext{
${ }^{11}$ Vercher Moll (2016), p. 350.

${ }^{12}$ Real Decreto-ley 3/2020, de 4 de febrero, de medidas urgentes por el que se incorporan al ordenamiento jurídico español diversas directivas de la Unión Europea en el ámbito de la contratación pública en determinados sectores; de seguros privados; de planes y fondos de pensiones; del ámbito tributario y de litigios fiscales.
} 
management of financial companies as a result of the commission of infractions or crimes of an economic nature is considered to be honorable.

The definition offered here is less broad than those contained in the regulations of the entities that operate in the financial market, ${ }^{13}$ because it appears to establish a clear distinction between the governing bodies, which have effective management as general directors and/or director's delegates, of the persons appointed to sell insurance within the company. However, in order to make an integrative interpretation of the Spanish Draft with the regulatory and supervisory regulations of the companies that operate in the financial market, the Dirección General de Seguros y Fondos de Pensiones seems to make a broad interpretation of the subjective requirements. However, this is not the "mens legis" of the Directive, because the subject of the requirement is an employee of the insurance entity, and the degree of requirement cannot be compared to that contained in (for example) Law 20/2015.

\section{The Appropriate Knowledge}

Apart from the requirement of honorability, art. 10.2 of the Directive imposes the obligation "that insurance and reinsurance intermediaries and employees of insurance and reinsurance undertakings and employees of insurance and reinsurance intermediaries comply with continuing professional training and development requirements in order to maintain an adequate level of performance corresponding to the role they perform and the relevant market".

In addition, the Directive states that the "member States need not apply the requirements referred to all the natural persons working in an insurance or reinsurance undertaking, or insurance or reinsurance intermediary, who pursue the activity of insurance or reinsurance distribution, but Member States shall ensure that the relevant persons within the management structure of such undertakings who are responsible for distribution in respect of insurance and reinsurance products and all other persons directly involved in insurance or reinsurance distribution demonstrate the knowledge and ability necessary for the performance of their duties".

The Spanish Law 3/2020 indicates in article 139 that insurance companies must ensure that employees directly involved in distribution activities, the person responsible for the distribution activity or, where appropriate, at least half of the people who are part of the management body responsible for the activity of distribution, possess appropriate knowledge and skills by passing training courses.

The recipients of this mandate are the insurance companies, and it applies to the same people as the honorability requirement, that is, the employees involved in the distribution of insurance products, the person responsible for said distribution or, at least half of the people who are part of the management body responsible. However,

$\overline{{ }^{13} \text { Vercher Moll (2017), p. } 120 .}$ 
the literal tenor of the precept is surprising, not because of the training requirement, whose purpose is satisfying the demands of the knowledge requirement, but because it does not place all the people to whom the aforementioned knowledge requirement is demanded on equal terms.

It is logical that employees, who have direct contact with the client are required to have certain knowledge, because it supposes a definite guarantee for the client or potential client. In this sense it is similar to article 25 of the (now repealed) Law $26 / 2006$, of July 17, on insurance and private reinsurance mediation, according to which the banking-insurance operator was obliged to establish a training program for employees that participated directly in insurance mediation. However, article 139 of the Spanish Law 3/2020 suffers from the same logical defect as article 25 did, because it does not seem reasonable that only half of the management body responsible for the distribution activity has to possess the appropriate knowledge and skills in this matter.

This requirement means breaking one of the most basic principles of corporate governance. Indeed, valuable work has been carried out by legal scholars ${ }^{14}$ in order to increase controls and ensure the sound and prudent management of commercial companies. In this regard, one could mention of the Proposal of the Businessmen's Circle of October 1996, the Code of Good Governance in Spain (Olivencia Code of 1998), the Aldama Report of 2003, the Unified Code of Good Governance of 2006 (Code Conthe) and its update in June 2013 and the Code of listed companies of February 2015 (Rodríguez Code).

It is the management body responsible for the distribution activity that must provide the greatest guarantees in terms of knowledge and fitness for the position, since otherwise the operational risk $^{15}$ of the company is increased, which may lead to a violation of clients' rights, as well as incurring sanctions imposed by the Dirección General de Seguros y Fondos de Pensiones, so the proper conclusion to draw is that all the people who compose the management body responsible for the distribution activity should possess appropriate knowledge and skills.

\section{Professional Training}

In order to maintain the adequate knowledge and skills for staff in the insurance distribution function, article 10.2 of the Directive includes the following obligation "home Member States shall ensure that insurance and reinsurance intermediaries and employees of insurance and reinsurance undertakings and employees of insurance and reinsurance intermediaries comply with continuing professional training and development requirements in order to maintain an adequate level of performance corresponding to the role they perform and the relevant market.

\footnotetext{
${ }^{14}$ Díaz Ruiz (2010), pp. 263-290; Esteban Velasco (2010), pp. 267-290.

${ }^{15}$ Vercher Moll (2018), pp. 143-162.
} 
To that end, home Member States shall have in place and publish mechanisms to control effectively and assess the knowledge and competence of insurance and reinsurance intermediaries and employees of insurance and reinsurance undertakings and employees of insurance and reinsurance intermediaries, based on at least 15 hours of professional training or development per year, taking into account the nature of the products sold, the type of distributor, the role they perform, and the activity carried out within the insurance or reinsurance distributor.

Home Member States may require that the successful completion of the training and development requirements is proven by obtaining a certificate".

This obligation is included in art. 139.2 of the Spanish Law 3/2020, which states that insurance companies must establish continuous training plans. However, the legal classificatory structure of the article could be improved because in the third paragraph it indicates that these training plans will be adapted to bases determined by the Dirección General de Seguros y Fondos de Pensiones. However, this point is a minor issue, the important one is the obligation imposed on the insurance company.

The continuous training programs must be adapted: to the products distributed, to the function staff perform and to the activities they carry out, and the training programs established must indicate, at least, the requirements to be fulfilled by the people for whom they are created and the means to be employed for their execution. The documentation corresponding to the training programs will be available at the Dirección General de Seguros y Fondos de Pensiones.

Therefore, in the opinion of the author, and in line with the distinctions between the staff who occupy the function of distributing the products, it is possible to differentiate various stages of training for employees depending on a host of factors: the type of product, the regulations that affect it, the client's rights and obligations, the procedure to be followed; the people responsible for the distribution activity and/or the people who are part of the management body responsible for the distribution activity. In addition to the aforementioned matters, the training must take account of the existing contingency plans, the company's governance system, the distribution of functions, the firm's procedures and policies, the alert systems in place for warning of outdated products, etc.

Finally, as already indicated, the Dirección General de Seguros y Fondos de Pensiones will establish, by resolution, the general lines and basic principles that, in terms of their content, organization and execution, will have to be met by the initial and continuous training programs for the employees of insurance companies, for the people responsible for the distribution activity as well as, where appropriate, for the people who are part of the management body responsible for the distribution activity.

\section{The Policies and Procedures}

Article 10.8 of the Directive establishes that "insurance and reinsurance undertakings shall approve, implement and regularly review their internal policies and appropriate internal procedures. Insurance and reinsurance undertakings shall 
identify a function to ensure the proper implementation of the endorsed policies and procedures".

This generic obligation is specified in art. 25 of the Directive. In its first paragraph, it states that the "insurance undertakings, as well as intermediaries which manufacture any insurance product for sale to customers, shall maintain, operate and review a process for the approval of each insurance product, or significant adaptations of an existing insurance product, before it is marketed or distributed to customers. The product approval process shall be proportionate and appropriate to the nature of the insurance product. The product approval process shall specify an identified target market for each product, ensure that all relevant risks to such identified target market are assessed and that the intended distribution strategy is consistent with the identified target market, and take reasonable steps to ensure that the insurance product is distributed to the identified target market".

Article 139.4 of the Spanish Law 3/2020, states that insurance companies will periodically approve, apply and review their internal policies and appropriate internal procedures. Likewise, insurers must determine a function that guarantees the correct execution of the approved policies and procedures, and the name of the person responsible for that function should be made available to the Dirección General de Seguros y Fondos de Pensiones.

This article, in fact, does not introduce any novelty, since the mandate that insurance companies should have appropriate policies and procedures is an obligation that is regulated in Law 20/2015, which transposes the Solvency II Directive. Perhaps, the only novelty at this point is given by the need for such documentation to be developed within the distribution function of the company's products.

In any case, as article 65.2 of Law 20/2015 states, the "governance system will include written corporate governance policies that will include, among others, a transparent and appropriate organizational structure, with a clear distribution and adequate separation of functions, effective mechanisms to ensure the transmission of information, and remuneration policies and practices appropriate to the characteristics of the companies"; so that it is a global obligation within the company that affects all of its functions.

Therefore, the policy of the commercial area should reflect the general principles of the company's commercial area and, in addition, the principles for approving specific insurance products. These principles should be set out in procedural manuals for the approval of insurance policies that the company wishes to market.

As a general rule, the policies of the commercial areas of insurance companies usually establish operating principles. With the clients: the company will be transparent, explain the insurance premium, explain the conditions of the contract, methods of payment of the premium, not oblige the client to contract, explain the contracting procedure to the client, clarify doubts to the client about the insurance policy. About the company's image: transmitting confidence to the client, training the commercial network about the insurance product and about the regulations, hiring highly competitive managers. On other insurance companies: watch over the products of other insurance companies, do not discredit other companies, etc. 
Article 139 indicates that the Dirección General de Seguros y Fondos de Pensiones will be informed of the name of the person responsible for the review of the policies and procedures. In the opinion of the author, this function can be assumed by the internal auditor, given that the evaluation is carried out within the company according to its functions.

Article 66.4 of Law 20/2015 indicates that "insurance and reinsurance companies will have an effective internal audit function, which will include checking the adequacy and effectiveness of the internal control system and other elements of the company's governance system and will be carried out in accordance with the provisions of the regulation of management, supervision and solvency of insurance and reinsurance companies and of the account audit activity", however, it emphatically states that "the internal audit function must be objective and independent of the operational functions", which leads us to distinguish between the internal audit function and the person responsible for executing the policies and procedures regarding the distribution of products.

Finally, it should not be overlooked that the norm does not require any subjective requirements for the person responsible for that function. At this point, given that the activity consists in the control of policies and procedures, which is nothing more than the deployment of the company's corporate purpose in the market, it would appear that the previously studied requirements should be equally applicable and enforceable on the person in charge of the control function of policies and procedures.

\section{The Supervision of the DGSFP}

To conclude, the article 139 of the Spanish Law 3/2020 gives the Dirección General de Seguros y Fondos de Pensiones (DGSFP) broad powers of control over insurance companies with regard to the distribution of their products. Thus, on the one hand, this Public Administrative body will have control over the registry that insurance companies must establish to enroll employees who participate directly in insurance distribution activities, as well as the person responsible for the distribution activity or, where appropriate, the people who are part of the management body responsible for the distribution activity. On the other hand, the insurance companies will register in the Register of the Dirección General de Seguros y Fondos de Pensiones the person responsible for the distribution activity and, where appropriate, the people who are part of the management body responsible for the activities of distribution.

However, the most important question is what happens if the DGSFP considers that an employee of the company does not have a good reputation or adequate knowledge to distribute the insurer's insurance. This can be a major problem because the insurer may have to dismiss the employee if he or she is not reputable. Perhaps, there is no problem if the employee does not have sufficient knowledge, because the insurance company can provide training in this regard. 
Spanish labour law does not regulate what happens when a company employee does not have a good reputation. The question is whether or not the dismissal is lawful. In this situation, the insurance company will have to supervise its employees in order to know if they have a good reputation or not. In this regard, if the DGSFP considers that an insurance company employee does not have a good reputation, the insurance company may have to dismiss the employee. It would be advisable to synchronise insurance distribution regulations with labour regulations.

\section{Conclusions}

The new European Directive creates a major transformation in the distribution of insurance. From a structural point of view, the new requirements for insurance companies are of incalculable impact at the moment. The main beneficiary of the reform is the client of the insurer, the reasons are of diverse nature but, fundamentally, because the client will be advised and informed in a prudent way before contracting an insurance policy. The client will be able to understand what he/she is contracting with the insurance company. In addition, the company's insurance salesmen must be knowledgeable, skilled and honest, which guarantees the best advice to the client.

In addition, the Directive controls all persons or companies distributing insurance. The Directive regulates both the conditions of access to the distribution market and the conditions of operation. This facilitates public control and supervision, which is carried out on the entire financial system, of any form of distribution of insurance products, whether directly by the insurer or by any other intermediary.

Perhaps there is a discrepancy between the Directive and the rules governing the insurance contract. The information obligations for the client are duplicated, those of the new Directive and those of the insurance contract. In addition, the Solvency II Directive also contains an obligation for the insurer to inform the client about the insurance contract. This leads to overprotection which is not necessary. The most important thing is that there should be an orderly information statute for the client.

Therefore, the question is: How many more information obligations will the client be more protected? In any case, these obligations aim to increase transparency in the insurance market as a guarantee of confidence, stability and good marketing of products. The important thing is that the distributor knows the customer and his needs, mainly because there are many clients with limited financial education and sometimes they do not really know their risks to be insured.

The new Insurance Distribution Directive stimulates the need to reform all Solvency II regulations. The governance system established by the Solvency II Directive was a major step forward in creating insurance companies with transparent structures. The requirements to have policies and procedures in each area of the governance system allowed for improved company management and for supervisors in each country to better perform their monitoring task. However, the new Directive advises that the Solvency II regulations should be reformed. 
The direct distribution made by the insurer and the new obligations for its employees make it advisable to create a specific area in the insurance company's governance system. The day to day shows how the insurers have a commercial area in their system of governance, but if I analyze the new Directive, it would be advisable to create a specific area more technical. The characteristics of this area could be at the same level as the other areas of the system of governance, such as the area of regulatory compliance, the actuarial area, the risk area, etc. This would increase the transparency of the insurer's structure.

Definitely, all these new demands are causing a profound reform in the corporate governance of insurance companies. The minimum requirements for the governance of insurance companies should be extended in order to recognise a new area of governance. The new area would be for the sale of the company's insurance products and the company would have its own standardised policies and procedures.

New requirements for insurance company employees who sell insurance are welcome. If the insurance company's management is required to be knowledgeable, skilled and honest, it is no exaggeration to say that lower-ranking employees are also required to be knowledgeable, skilled and honest, especially since the employees who distribute the insurance have daily contact with the customer. If the Solvency II regulation establishes the "fit and proper" principle for the insurance company's management, the same principle now applies to the employees who distribute the insurance. Obviously, the regulations cannot require the same knowledge of the insurance company's management as of the employees, but this is an important step towards the professionalization of the employees.

In order to ensure that employees comply with the requirements, the regulations establish continuous training for them. This idea is important, above all because insurance regulations, both life and non-life, are constantly developing and changing. Recycling knowledge will benefit customers, mainly because they will get better advice and because their rights will not be violated. In addition, employees will be able to understand which clauses in the insurance contract are illegal, so they will not use these clauses. Therefore, the insurance company's employees will also carry out quality control of the products that the insurer offers to the public.

On the other hand, new demands on the knowledge, skills and reputation of employees increase the internal risks of the insurance company. Auditors should analyse whether employees who distribute insurance are actually trained to do so. In order to avoid problems, the insurance company should hire employees with the appropriate knowledge or conduct training courses and examinations.

The supervisory bodies of each country will be able to know the employees who distribute insurance. This control will enable employees to complete a questionnaire to determine whether they can distribute insurance or need further studies to do so. In addition, the supervisors in each country will be able to sanction the insurance companies if the employees do not meet the requirements of knowledge, aptitude and honesty. Therefore, the principle of "fit and proper" is established for the employees of the insurance company that distributes insurance products.

In short, transparency, both in customer information and in the insurer's governance system, is the key to consumer satisfaction and confidence. Furthermore, it 
influences consumer loyalty, which is in the insurer's interest. Obviously, maintaining high levels of transparency entails costs, but this is a benefit for the insurer in the long term because it offers a good reputation image. In today's competitive insurance market, reputational risk is a major risk that insurers must control and mitigate.

\section{References}

Bataller Grau J (2007) La ley de ¿mediación? de seguros y reaseguros privados: su ámbito de aplicación. In: Comentarios a la Ley de mediación de seguros y reaseguros privados. ThomsonCivitas, Cizur Menor, pp 112-113

Del Caño Escudero F (1971) Derecho Español de Seguros. Imp. Góngora, Madrid

Díaz Ruiz E (2010) Códigos de conducta y mercados financieros: cuestiones generales. In: Códigos de conducta y actividad económica: una perspectiva jurídica. Marcial Pons, Madrid, pp 263-290

Esteban Velasco G (2010) Una aproximación a los códigos de buen gobierno en el marco y heterogéneo fenómeno de los códigos de conducta. In: Códigos de conducta y actividad económica: una perspectiva jurídica. Marcial Pons, Madrid, pp 267-290

Hofmann A, Neumannm JK, Pooser D (2018) Plea for uniform regulation and challenges of implementing the new Insurance Distribution Directive. In: The Geneva Papers, 43, Geneva, p 740

Marano P (2017a) La "Mifidización": el atardecer de los seguros de vida en la normativa europea sobre seguros? Revista Española de Seguros 171-172:416

Marano P (2017b) Sources and tools of the insurance regulation in the European Union. In: Insurance regulation in the European Union, solvency II and beyond. Palgrave Macmillan, Cham, p 10

Miranda Serrano L (2017) Transparencia en la contratación de seguros: condiciones generales y particulares. Revista Española de Seguros 171-172:287-320

Peñas Moyano MJ (2017) El deber general de información de los aseguradores a los tomadores, asegurados y beneficiarios. Revista Española de Seguros 171-172:321-340

Quintans Eiras MR (2018) Información como motor de la protección del asegurado en la comercialización de seguros. Revista Española de Seguros 175:373-420

Sánchez Calero F (1961) Curso de Derecho del Seguro Privado. Ediciones Nauta, Bilbao

Tapia Hermida AJ (2016) Los puntos críticos del proceso de implantación del sistema de gobierno de las entidades aseguradoras. Revista Española de Seguros 167:331-350

Vercher Moll J (2016) Las condiciones de acceso al mercado de las entidades aseguradoras. Marcial Pons, Madrid

Vercher Moll J (2017) Los requisitos subjetivos de los que ostentan la dirección efectiva en las sociedades del mercado financiero. Revista de Derecho Bancario y Bursátil 146:120

Vercher Moll J (2018) La transcendencia jurídica de la gestión de riesgos en las entidades de crédito. Revista de Derecho Bancario y Bursátil 150:143-162 
Open Access This chapter is licensed under the terms of the Creative Commons Attribution 4.0 International License (http://creativecommons.org/licenses/by/4.0/), which permits use, sharing, adaptation, distribution and reproduction in any medium or format, as long as you give appropriate credit to the original author(s) and the source, provide a link to the Creative Commons licence and indicate if changes were made.

The images or other third party material in this chapter are included in the chapter's Creative Commons licence, unless indicated otherwise in a credit line to the material. If material is not included in the chapter's Creative Commons licence and your intended use is not permitted by statutory regulation or exceeds the permitted use, you will need to obtain permission directly from the copyright holder. 